\title{
FEATURES OF PROJECTING THE HIGHER EDUCATIONAL ENVIRONMENT IN THE CONTEXT OF TRAINING TEACHERS TO THE ORGANIZATION OF DIALOGUE EDUCATION OF PRIMARY SCHOOL PUPILS
}

\author{
KATERYNA FOMIN
}

\begin{abstract}
The article substantiates the urgency of the problem of professional training of future teachers to organize the dialogue training of primary school students in the context of integration into the European educational space and the conceptual foundations of the New Ukrainian school. The main methodological foundations of the study are defined: philosophical and pedagogical anthropology, philosophical and pedagogical hermeneutics and philosophical and pedagogical synergetics. The author substantiates the essence of the educational dialogue and its advantages, in contrast to the traditional teaching methods at primary school. The contents of dialogue communication and its components are determined. The principles of organization of dialogue training for junior pupils are described. The indicative model of forming the readiness of the future teacher of elementary school for the dialogue education is presented, in which the main components of this readiness (motivational, cognitive, socially-communicative and operationaltechnological) are singled out. It is emphasized that the effectiveness of projecting the educational environment for the implementation of the idea of dialogue education for junior pupils depends to a large extent on the level of the teacher's communicative culture and the components of this culture (communicative settings, knowledge, communicative skills, etc.) are described.
\end{abstract}

Keywords: dialogue training, professional readiness of the future teacher, primary school pupils, model of professional training, methodological approaches, dialogue educational environment of elementary school.

\section{INTRODUCTION}

We see the urgency of the above problem in the numerous challenges that each national education system faces today in the context of integration into the European educational space. Dehumanization of many aspects of modern life in post-Soviet countries, "the alienation of a person from other people, from products of labor, nature, cultural traditions" [2], exacerbates the problem of projecting the educational environment based on mutual understanding, democracy, humanism, partnership. Actually, organization of dialogue training serves as an effective means of development of the communicative sphere of personality in the context of solving the outlined problem. The essence of dialogue teaching, according to Yu. Pidborskyi, is that "it is the dialogue itself that has an interpersonal 
subject-subject character, a dialogue based on equality of the parties, while studying, encourages those who are learning to cooperate in generating new ideas, thoughts, views. In addition, the dialogic form of teaching is more progressive than monologue, since it affects the role and emotional sphere, develops perseverance, points to the need for self-education" [12, p. 133].

Dialogue communication focuses not only on the needs of the teacher, but also on the interests and needs of students; accumulation of the potential of agreement and cooperation, freedom of discussion, transfer of knowledge and social norms as personal experience requiring individual reflection; the desire for creativity, personal and professional growth, improvisation, readiness for search; the domination of methods and techniques aimed at the organization of independent activities of individuals, the desire for objective control of the performance of pupils, an individual approach and taking into account the multi motivation of their behavior; personal (but not status) equality of the teacher and students, subject-subject relations between them [15, p. 378-379].

Based on the fact that dialogue is a form of interpersonal communication, in which two communicants take part, resulting in an exchange of thoughts, ideas, reveals the creative potential of everyone; in the educational process a special dialogue environment is created that enables the development of the intellectual and emotional qualities of the pupil (student) on the basis of cocreation, cooperation, empathy, mutual respect and mutual enrichment.

\section{RESULTS AND DISCUSSION}

\subsection{Methodological Approaches to the StUdy of the Identified Problem}

While projecting a dialogue educational environment in the process of training future teachers of primary school, the basic methodological principles have been defined: philosophical and pedagogical anthropology, philosophical and pedagogical hermeneutics and philosophical and pedagogical synergy [7].

Philosophical and pedagogical anthropology as the methodological basis of the study allows to thoroughly analyze the essence of human existence, his spiritual world; to realize that each person has his own unique inner center and world, which requires a thorough study and humane psychological and pedagogical influence. At the same time, in the context of this methodological approach, dialogue is considered to be a form of teaching in the conditions of freedom for a teacher and a student, and the interaction on the basis of humanism. The implementation of the principle of dialogue in the educational process is a real change in the vector: from knowledge to creative thinking and human culture. Finally, analyzing the problem of dialogue teaching the personification of the message that the interlocutor expresses in the dialogue should be taken into account, because without this fact exchange of views may be formal.

In the context of philosophical and pedagogical hermeneutics, the cognitive processes that take place during the dialogue training should maximally take into account not only its content aspects, but also functional, and hence the value of human understanding. The creative application of hermeneutics in the educational process opens up new horizons of mastering languages, (primarily in their native language) as effective means of human understanding. Therefore, it is important that the future teacher realizes that the forms and methods of dialogue training are in constant development, which requires constant monitoring of their application in accordance with actual changes in human existence as well as cultural and social changes.

Philosophical and pedagogical hermeneutics opens up new meanings of the educational process and human being; it is designed to consistently form the scientific and humanistic worldview of subjects of teaching. At the same time, this methodology proves that any dialogue internally contains both elements of understanding and misunderstanding. And this requires the level of dialogue training that minimizes the processes of misunderstanding between subjects of communication.

The following methodological approach is a philosophical and pedagogical synergetic, which, on one hand, allows us to thoroughly analyze the content and conditions of the organization of dialogue training; on the other hand - enables finding the reasons for its imperfect organization and actively 
searches for ways to improve it. Focusing on the synergetic methodology, we have designed an indicative model of a future teacher who would have high professional skills and skills of dialogue training.

At the same time, this theory helps to analyze the formation of a student's and teacher's worldviewpoints, skillfully apply corrective effects in order to inspire them, and also makes it possible to find out the role and place of the motivational-value component in preparing the future teacher for dialogue training. Finally, the synergetic concept involves updating the principles of activity, autonomy, creativity, when subjects of dialogue training become open, free, aspiring to their development and self-development [7].

\subsection{Principles of Organization of Dialogue Teaching in Primary School}

In modern pedagogical science and practice, considerable attention is paid to the educational dialogue, in contrast to the traditional teaching methods, which are mostly focused on the explanatoryreproductive type of education. Figure 1 shows the main characteristics of the dialogue training used in a typical foreign school.

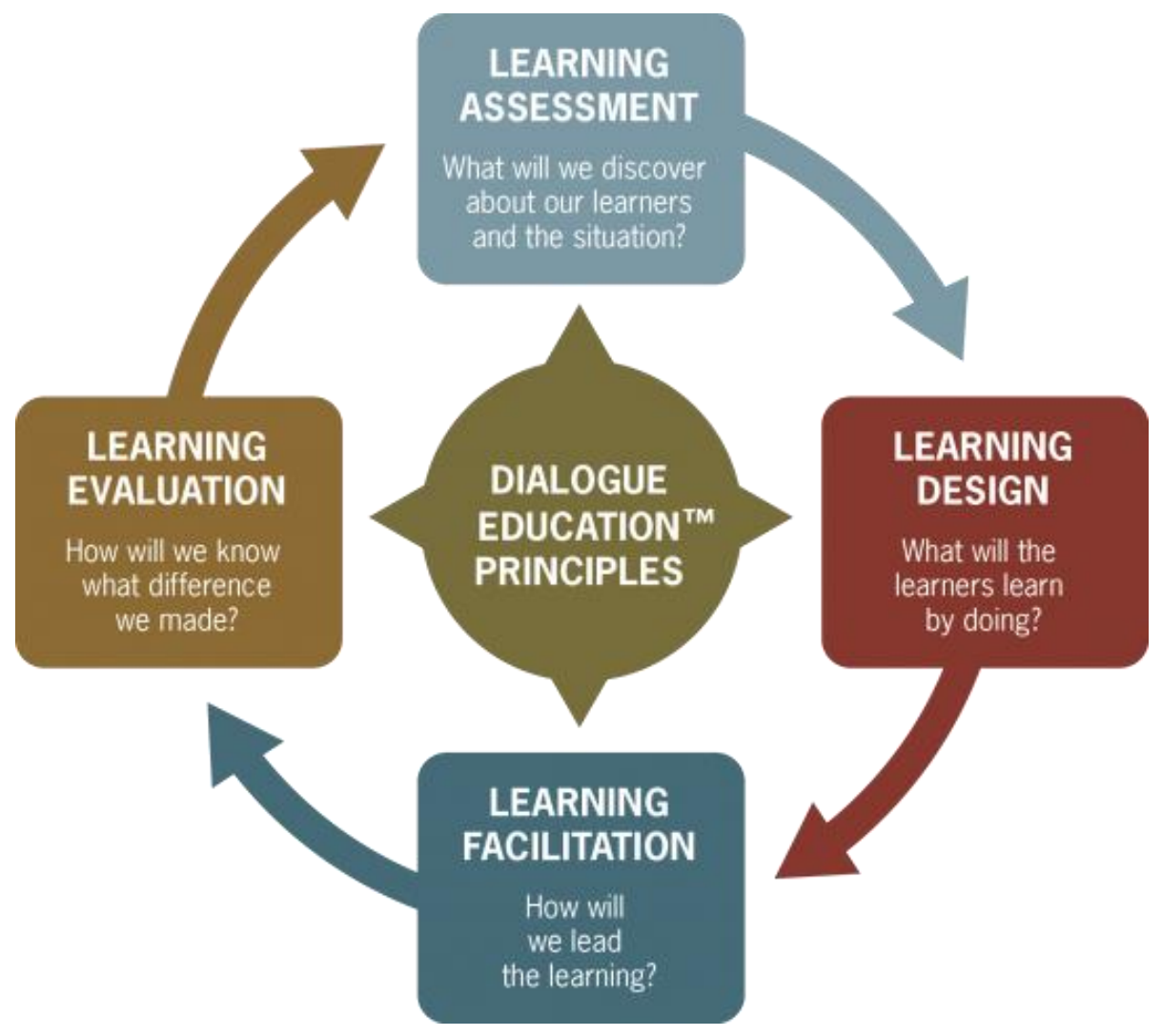

Fig. 1. Training dialogue and other teaching methods [1].

Foreign scholars (P. Freire, M. Knowles, J. Vella) determine10 principles at the heart of dialogue education:

1) learning needs and resources assessment to ensure the workshop is responsive to the learner's specific challenges and objectives;

2) a safe environment and process for all types of learners and learning needs;

3) content sequence and learning reinforcement that continuously support learners in reaching their goals;

4) active learning through praxis: the synthesis of action enriched by reflection, or learning by doing;

5) respect for each unique learner as the focus of their own learning; 
6) addressing all three learning domains: cognitive (ideas), affective (feelings) and psychomotor (actions);

7) workshop design that gives learners an immediate experience of their desired learning;

8) collaboration through teamwork, small groups and pairs for lively interaction, discussion and purposeful dialogue;

9) content and methods that keep people immersed and engaged in the learning experience;

10) mutual accountability: the instructor's accountability to the learners, and the learners' accountability not only to the instructor but - most importantly - to themselves [1].

The principles of organization of dialogue training are based on general didactic principles for the teaching of primary school students. However, we have identified some specifics. So let's try to characterize them.

We regard the principle of humanism as the main in the organization of dialogue training at the New Ukrainian School, which declares the child as the highest value of society, respect for his rights and freedoms, as well as empathy as the ability to accept the views of other communicants and accordingly regulate their own emotional states.

The principle of nature correspondence involves taking into account the multifaceted nature of the primary schoolchild in the process of organizing dialogue training, in particular his psychological, age, social, national, gender and other peculiarities.

The principle of scientific organization of educational dialogue involves the scientific and pedagogical search and implementation of teacher's pedagogical activity, taking into account the causal relationships in the selection of material for discussion, analysis, modeling of situations for dialogue interaction.

The principle of communicative orientation is the ability to express opinions and beliefs clearly and reasonably, the ability to listen to the interlocutors carefully, and to design situations that take into account the abilities, needs and interests of the educational community, etc.

The principle of simulation of problem situations in teaching involves the creation of typical and nontypical situations, each of which serves as a functional unit of speech. At the same time, in the context of dialogue interaction, each participant in the educational process must clearly understand his or her role in the process of solving the problem situation and to improvise it.

The principle of the relationship between theoretical knowledge and practice is the comprehension of the significance of theoretical teaching and practice-oriented experience in the content of education, the use of empirical knowledge in the process of dialogue learning activities.

The principle of anthropological orientation is the orientation of the content of vocational education into the integrative study of a person, the recognition of the self-worth of an individual as an active subject of the educational process, the consideration of personal peculiarities of his development in the process of mastering professionally significant values on the principles of humanism and spirituality [5, p. 211].

The principle of verbal ethics - in the process of dialogue teaching students should follow the basic principles of a person-centered approach and try to create a positive atmosphere for the exchange of information. For this purpose the necessary qualities of the teacher are: politeness, tolerance, restraint, benevolence, etc.

The principle of a pedagogical partnership is the collaboration of the school and the student's family in achieving the goals of the educational dialogue, based on: mutual respect, trust and a benevolent attitude towards all participants in the educational process, shared leadership and responsibility for solving pedagogical situations and fulfilling their obligations.

The principle of pedagogical optimism in teaching is based on emotional elevation, tolerance, psychological comfort in the appropriate dialogue environment. As a result of the dialogue, the truth must be born, which the participants are looking for together. Actually, the moral and psychological atmosphere promotes the search for this truth in the process of exchange of opinions and ideas that promotes the creative potential of communicants, their intellectual and emotional qualities, and so on. 


\subsection{The Approximate Model of the EdUcational EnVironment of a Higher Education} INSTITUtion IN THE CONTEXT OF TEACHER Training FOR THE ORganization OF Dialogue Training For PRIMARY SCHOOl PUPILS

In the opinion of L. Major, M. Brugha, C. Froehlig, S. Walker, R. Higham, and M. Vrikki (2018), the dialogue can be defined in connection with other processes, such as: communication, non-verbal interaction and a set of features of discourse. There is widespread debate about whether the dialogue can be defined as a special form of communication with internal connections to designing knowledge and academic learning, or it is better served as an umbrella term for all human interaction. After all, the consideration of interconnected elements of the dialogue often leads to some difficulties in defining it in practical terms [10, p. 15].

M. Bastun emphasizes that "the creation of dialogically and culturally oriented personally oriented educational technologies is an adequate response to inquiries" [2], which today are facing the educational system of Ukraine. N. Goydosh defines dialogue technologies as: "a set of forms and methods of teaching based on the dialogue thinking in interacting didactic systems of the subjectsubject level: student-teacher, student-author, teacher-author, etc." [8, p. 72-73].

I. Todorova and O. Shtepa singled out the main components of dialogue communication in the educational process:

organizational-behavioral (skills to organize a frank conversation with schoolchildren);

interpersonal-reflexive (elements of communication that provide an adequate perception and understanding of the teacher by students, themselves, situations, etc.);

subject-reflexive (factors that provide a substantive, decentralized analysis of the educational material and the process of its learning) [14, p. 51-53].

The training of future teachers of primary education to the organization of dialogue teaching of students is understood as a holistic system that contains the main components in the following areas:

1) scientific - aimed at studying the laws of professional and pedagogical formation and development of the future specialist in mastering the methods, means and tools for modeling the educational process at the New Ukrainian school;

2) applied - involves the development of educational, methodological and organizational content of the process of teaching / teaching in primary school on the basis of the use of innovative educational technologies, especially the methods of dialogue training.

The effectiveness of projecting the educational environment for the implementation of the idea of dialogue education for primary students largely depends on the level of communicative culture of the teacher, which is understood as "complex socio-pedagogical phenomenon, consisting of several interrelated components (communicative settings, knowledge, communicative skills that are implemented under certain conditions and depend on external conditions and internal factors)" [2].

O. Semenog characterizes the necessary attributes of the teacher's communicative culture, which are necessary for organization of productive dialogic teaching of students. It is "content, accuracy, logic, correctness, conciseness of presentation of ideas, proof, correctness and relevance of the use of terms, purity and stylistic ability" [13, p. 159].

Content, in the opinion of the scientist, means complete expression of the opinion of the statement, observance of the logical sequence, relevance and reasonableness. The correctness of speech is compliance with the norms of modern literary language. The richness of speech is expressed in the ability of the teacher to actively use the linguistic units of various structural levels. Stylistic skill ensures compliance with the specifics of a particular functional style, such as speech, to the purity of speech indicated by the correct normative pronunciation, the absence of non-literary components in the speech, spatial or professional jargon, chancelleries, parasite words, unjustified repetitions [13, p. 159].

In the dialogue training, the installation for an effective information exchange is understood as the readiness of the future teacher to organize the effective communication of students and their motivation to mobilize at the psychological level. In other words, it is a guide to a certain type of activity, which is a dialogue training. 
Modern scholars (H. Muhonen, H. Rasku-Puttonen, E. Pakarinen, A. M. Poikkeus, M.K. Lerkkanen) consider the model of formation of students' knowledge in the process of educational dialogue. In fact, in their work, they offer specific episodes of educational dialogues on the three main types of knowledge based on: facts, views and experiences. Scientists pay a lot of attention to the formation of students' knowledge, which reflects the life experience that is the subject of dialogue [11].

According to N. Basyuk, the communicative culture of the teacher synthesizes the following components: knowledge of the evolution of the general theory of communication, the history of the doctrine of pedagogical communication; knowledge of socio-cultural norms and ethics of pedagogical communication; knowledge of psychological and pedagogical regularities of effective pedagogical communication [3].

At the same time, it is impossible to organize a dialogue with children using only theoretical knowledge in this field. Future teacher of a new Ukrainian school must possess a system of skills:

- to organize and manage the dialogue process while studying;

- to create a positive communicative atmosphere for the exchange of ideas and opinions;

- it is advisable to pedagogically stimulate pupils' communication;

- to apply advanced dialogue teaching technology;

- to motivate students to create or solve a problem-based teaching situation through productive dialogue;

- effectively to use means of verbal and non-verbal communication;

- to make emotional contact and listen to the interlocutor, etc.

Regarding the readiness of future primary school teachers to organize productive educational dialogue, attention should be paid not only to the emphasis on communicative abilities, but also to the lesser extent on other qualities such as: intellectual qualities, motivation for pedagogical activity, love for children, emotional balance, empathy, tolerance, professional responsibility, a high level of moral culture, readiness for innovation, a desire for self-improvement and self-education, etc.

In the context of solving the problem under study, in our opinion, there are specific professional characteristics of the teacher (according to M. Chobitko). The scientist introduced it in the form of such blocks: 1) motivation; 2) direction, 3) activity; 4) intelligence; 5) logic; 6) heuristic; 7) morality; 8 ) aesthetics; 9) communicative; 10) self-government; 11) self-development; 12) individuality and others $[6$, p. 74].

Therefore, in designing the readiness of the future primary school teacher to organize the dialogue teaching of students, we determine the following components (Figure 2):

The motivational component is the interest in the teaching profession as a whole and the need to use the methods of dialogue training in order to improve the educational process in primary school; interest in innovative dialogue technologies; orientation towards achievement of high educational results; identification of creativity in the formation of an interactive educational environment for primary school for professional self-improvement and personal development of students [4].

The cognitive component is the awareness of future teachers about the methodology of effective organization of dialogue training at primary school, the latest technologies for the formation of a dialogical educational environment; professional pedagogical competence in monitoring and improving the educational process and activating the dialogue activity of primary school pupils.

Socio-communicative is the ability of the future teacher to organize constructive interaction in the dialogue environment of the participants in the educational process (students, parents, teachers, etc.); communicative and organizational skills, ability to solve problematic pedagogical situations, to create an atmosphere of creative cooperation, co-creation, partnership; to use verbal and non-verbal communication tools to optimize the educational process at primary school.

The operational-technological component includes analytical skills of the teacher in organizing and optimizing the educational process in primary school; prognostic skills, which are manifested in the implementation of innovative dialogue technologies in school practice; modeling skills that manifest themselves in the ability to create their own educational content, taking into account communicative skills, cognitive needs and interests, and the experience of primary school pupils. 


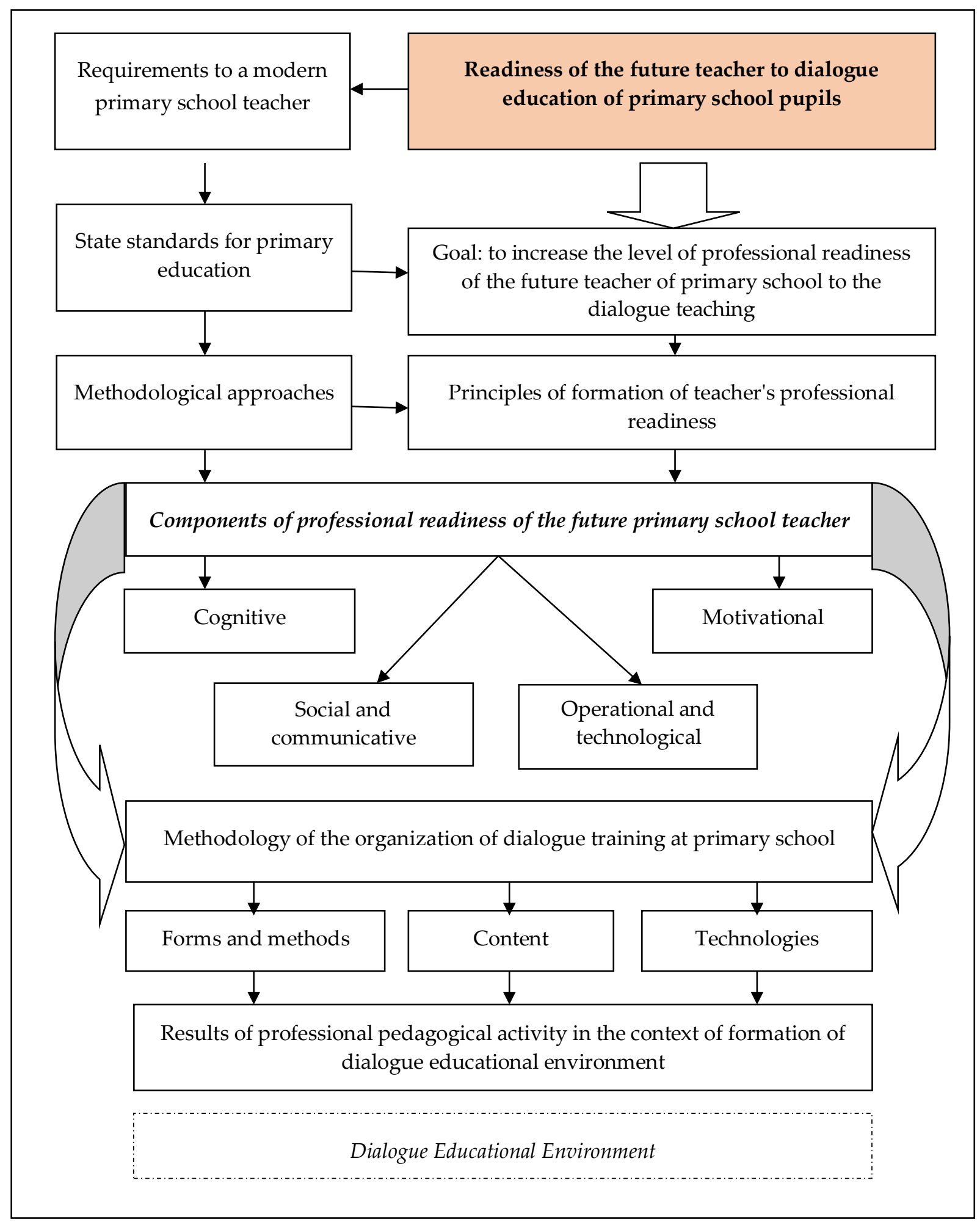

Fig. 2. Approximate model for forming the readiness of the future primary school teacher for the dialogic study of students

In Fig. 2 we summarize the theoretical material on the preparation of the future teacher for the formation of effective dialogue education in the educational environment of the elementary school. In particular, the purpose of the training, the methodological approaches and principles of forming the readiness of students for the relevant activities, the components of this readiness and the methodological principles of the technological tools, which ultimately leads to the achievement of the goal of our study, are presented here. 


\section{CONCLUSIONS}

Dialogue teaching is primarily problem-based teaching. After all, in order to stimulate students to solve educational creative tasks, to actively discuss them in a group, it is necessary to create a situation in which the pupils will be interested, and they will have different views on the same problem. Actually, collision of different opinions, their ability to express, defend, listen to each other, analyze, draw conclusions, show tolerance and restraint will make it possible to create interactivity, effective interaction of learners.

The process of organizing dialogue training is somewhat complex for a young teacher, because he needs some experience in "management" of a class, professional competence. The main difficulty is that the preparation and the very process of dialogue requires a lot of time, it is necessary to clearly identify certain topics of the content of primary education that are to be studied using the proposed method, since not all material can be studied through educational dialogue. However, the use of this method is possible only with proper theoretical and practical training of students.

At the same time, dialogue training has certain advantages, as it contributes to the development of a communicative culture of a teachers and students; motivates active interaction in the group, cooperation, partnership; develops independent creative thinking and intellectual abilities, etc.

Prospects for further scientific research we see in the development of specific methodological recommendations on the practical solution of the problem of preparing future teachers of primary education for the dialogue teaching.

\section{REFERENCES}

[1] About Dialogue Education. Global Learning Partners. Available at: http://www.globallearningpartners.com/about/about-dialogue-education

[2] Bastun M.V. Modeling of the educational environment in the context of dialogue of cultures. Available at: http://lib.iitta.gov.ua/7272/1/Bastun_9.pdf (in Ukrainian)

[3] Basjuk N.A. The communicative culture of the teacher of higher education as the main aspect of pedagogical communication. Master of Nursing: Ukrainian Scientific and Practical Magazine, 1 (11) (2014), 51-56. Available at: http://eprints.zu.edu.ua/20252/1/Basjuk1.pdf (in Ukrainian)

[4] Budnyk O. Motivation of students to the professional pedagogical activities. Scientific Bulletin of Chetm. Section of Pedagogy, 1 (2018), 53-63. Available at: http://yadda.icm.edu.pl/yadda/ element/bwmeta1.element.desklight-be55418b-854b-4b62-9d82-75a65bd087ac

[5] Budnyk O. Professional Training of Primary School Teachers to Social and Educational Activities: Theory and Practice. Seredniak T.K., Dnipropetrovsk, 2014. (in Ukrainian)

[6] Chobitko M.H. Personally oriented vocational training of the future teacher: theoretical and methodological aspect, monograph. Brama-Ukraine, Cherkasy, 2006. (in Ukrainian)

[7] Fomin K. Research of the Problem of Dialogue Education Implementation in the Future Primary School Teachers' Training Process: Philosophical and Anthropological Approach. Scientific Bulletin of Chetm. Section of Pedagogy, 1 (2018), 21-32.

[8] Hoidosh N. Dialogue teaching technologies in the system of training future teachers of foreign languages. Humanitarium. Pedagogy, 26 (2012), 70-75. Available at: http://ephsheir.phdpu.edu.ua:8081/xmlui/bitstream/handle/8989898989/625/70_75.PDF?sequence=1\&is Allowed=y (in Ukrainian)

[9] Littleton K., Howe Ch. (Eds.) Educational Dialogues: Understanding and Promoting Productive Interaction. Routledge, London, 2010. 
[10] Major L., Kershner R. (Eds.) A Dialogue About Educational Dialogue: Reflections on the Field and the Work of The Cambridge Educational Dialogue Research (CEDiR) Group. Faculty of Education University of Cambridge, 2018. Available at: http://www.academia.edu/37916282/A_Dialogue_About_ Educational_Dialogue_Reflections_on_the_Field_and_the_Work_of_The_Cambridge_Educational_Dial ogue_Research_CEDiR_Group

[11] Muhonen H., Rasku-Puttonen H., Pakarinen E., Poikkeus A.-M., Lerkkanen M.-K. Knowledge-building patterns in educational dialogue. International Journal of Educational Research, 81 (2017), 25-37. doi: 10.1016/j.ijer.2016.10.005.

[12] Pidborskyi Yu.H. Application of dialogue technologies in the educational process. Journal of Taras Shevchenko National University of LNU, 22 (1) (257) (2012), 132-139. Available at: http://nbuv.gov.ua/UJRN/vlup_2012_22(1)_20 (in Ukrainian)

[13] Semenog O. Role and place of dictionary in the development of communicative culture of personality of researcher. Osvita Doroslykh: Teoriya, Dosvid, Perspektyvy, 7 (2013), 159-167. (in Ukrainian)

[14] Todorova I.S., Shtepa O.H. Teacher training system for pedagogical communication. Higher and Secondary Education, 14 (1989), 51-56. (in Ukrainian)

[15] Vasianovych H.P. Selected Works: in 5 v. V.3: Pedagogical Ethics. SPOLOM, Lviv, 2010. (in Ukrainian)

[16] Ziaziun I.A. Intellectual and creative development of personality in conditions of continuous education. In: Ziaziun I.A. (Ed.) Continuing Vocational Education: Problems, Research, Perspectives. Vipol, Kyiv, 2000, 11-57. (in Ukrainian)

Address: Kateryna Fomin, Vasyl Stefanyk Precarpathian National University, 57, Shevchenko Str., IvanoFrankivsk, 76018, Ukraine.

E-mail: aerosweett@ukr.net

Received: 26.12.2018; revised: 21.03.2019.

Фомін Катерина. Особливості проектування освітнього середовища закладу вищої освіти у контексті підготовки педагогів до організації діалогічного навчання молодших школярів. Журнал Прикарпатського університету імені Василя Стефаника, 6 (1) (2019), 67-75.

У статті обгрунтовано актуальність проблеми професійної підготовки майбутніх педагогів до організації діалогічного навчання учнів початкової школи в контексті інтегрування до європейського освітнього простору та концептуальних засад нової української школи. Основними методологічними засадами дослідження визначено: філософсько-педагогічну антропологію, філософсько-педагогічну герменевтику та філософсько-педагогічну синергетику. Обгрунтовано сутність навчального діалогу та його переваги, на відміну від методів традиційного навчання у початковій школі. Визначено зміст діалогічного спілкування та його компоненти. Охарактеризовано принципи організації діалогічного навчання молодших школярів. Представлено орієнтовну модель формування готовності майбутнього педагога початкової школи до діалогічного навчання учнів, в якій виокремлено основні компоненти цієї готовності (мотиваційний, когнітивний, соціально-комунікативний та операційнотехнологічний). Автором наголошено, що ефективність проектування освітнього середовища для реалізації ідеї діалогічного навчання мододших школярів значною мірою залежить від рівня комунікативної культури педагога та охарактеризовано складники цієї культури (комунікативні установки, знання, комунікативні вміння та ін.).

Ключові слова: діалогічне навчання, професійна готовність майбутнього вчителя, учні початкової школи, модель професійної підготовки, методологічні підходи, діалогічне освітне середовище початкової школи. 